\title{
METHODOLOGY AND RESULTS OF EXPERIMENTAL DETERMINATION OF CORN GRAIN ELASTICITY MODULUS
}

\author{
Dmitriy Bakharev, Alexander Pastukhov, Sergey Volvak, Alexander Dobrickiy \\ Belgorod State Agricultural University named after V. Gorin \\ baharevdn_82@mail.ru, pastukhov_ag@mail.ru, volvak.s@yandex.ru, dobrickiy_aa@bsaa.edu.ru
}

\begin{abstract}
Theoretical justification of rational design parameters of effective threshing and separation devices for corncobs of various subspecies requires knowledge of the mechanical characteristics of the grain, of which the modulus of elasticity is the most significant. At the present stage of the threshing theory development the numerical values of the modulus of elasticity of grain of various subspecies of corn require experimental clarification. The complex geometrical shapes of the grains of dent, flint, sugar and pop corn do not allow determining their modulus of elasticity by the conventional method of tensile testing. To solve this problem, an experimental-theoretical method was proposed for determining the modulus of elasticity of corn grain and refining its Poisson's ratio during compression, based on the application of Hertz's theory. The essence of the method is to determine the micro deformations of corn grains with a complex geometric shape and located in the platform under the action of special cylindrical indenter, by continuous loading to the boundary value of the elastic deformation of the grain shell. Resistance to displacement of the cylindrical indenter in the protective fruit shell of grain is controlled by analytical weight equipment of II-high accuracy class, and deformation by a micrometric depth meter of the first accuracy class. The humidity content of the test grain is in the range of $12.8 \ldots 13.4 \%$ and controlled in laboratory conditions by means of equipment for controlling the humidity content of cereals. As a result of the studies, numerical values of modulus of elasticity for protective fruit shell were established of grain of dent corn $78 \ldots 127 \mathrm{MPa}$, flint corn 98..125 MPa, sugar corn 97...124 MPa and popcorn 127..169 MPa and the physical causes of their numerical difference were analyzed. The research results make it possible to carry out more accurate theoretical and engineering calculations when designing innovative threshing and separation devices for the cobs of seed, food and forage corn of various subspecies.
\end{abstract}

Keywords: corn, subspecies, grain, fruit shell, modulus of elasticity.

\section{Introduction}

According to the FAO, wheat, rice and corn are the main crops that ensure global food security. The potential for wheat yields is 98 centner per hectare, rice -150 centner per hectare, and maize is much more. For example, in 2020 in the USA, the National Corn Growers Association (NCGA) published data that farmer David Hula of Charles City, Virginia, growing a hybrid P1197 the Pioneer ${ }^{\circledR}$ brand, set a new world yield record of 386.6 centners per hectare. Therefore, at the present stage of the development of agricultural science, corn is given special attention. In addition to high yields, corn is distinguished by the presence of a number of subspecies characterized by various mechanical, technological and taste characteristics. In particular, the main industrial subspecies include dent corn, flint corn, sugar corn, flour corn, waxy corn and popcorn [1].

The production of corn seed grain of these subspecies requires an effective technology for harvesting the cobs and processing them in stationary conditions using machines that maintain yield potential by minimizing macro and microdamage to the grain. Among such machines, the most attention needs to be paid to threshing and separation systems, since threshing is the most extreme process in relation to macro and micro damage of grain. It is also important to minimize grain damage during repeated transport operations.

The creation of efficient machines requires substantiation of kinematic and force parameters of the working organs in connection with the mechanical properties of grain, among which Young's modulus is the most important. In this context, it is advisable to speak not of Young's modulus of grain as a whole, but of Young's modulus of its outer protective fruit shell. This knowledge will make it possible to carry out more accurate scientific and engineering calculations when designing working organs of effective threshing, separating, transporting and other systems for processing corn, operating in stationary conditions of specialized enterprises.

Corn grain of various subspecies differs significantly in the shape of external surface, thickness of protective fruit shell of grain, thickness of the aleuronic layer and the layer of seed shells covering endosperm of different composition. Therefore, Young's modulus of the protective fruit shell of grain 
of various subspecies is different, but in a well-defined range of values, which indicates the need for appropriate scientific studies followed by detailed analysis of the results.

The complexity of the grain shape and small size do not allow Young's modulus of protective fruit shell of grain to be investigated by the conventional method of tensile testing. In the process of threshing corn cobs, the grain undergoes a shock and compressive effect from the working organs, therefore, the most natural and appropriate method for determining the Young's modulus of the grain shell is the method of compressing it within the limits of elastic deformation. In this case, the main hypotheses of the contact problem of Hertz's theory are applicable, and the Young's modulus determination procedure becomes practically feasible without the use of ultra-complex laboratory equipment.

The equipment scheme for the experimental study of Young's modulus of corn grains by compressing it within the limits of elastic deformation of the grain shell is simple, reliable, convenient to operate and is presented in Fig. 1.

a)

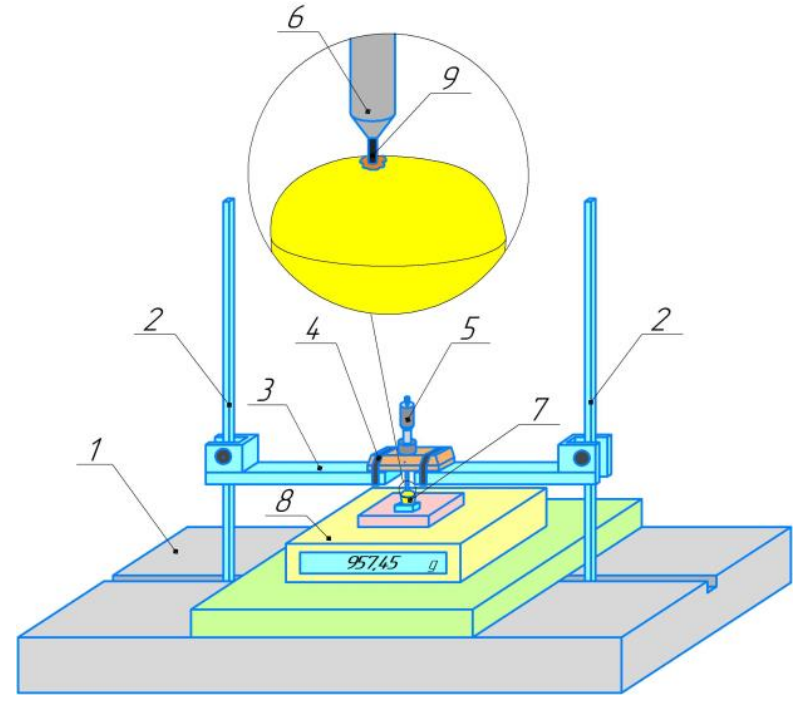

b)

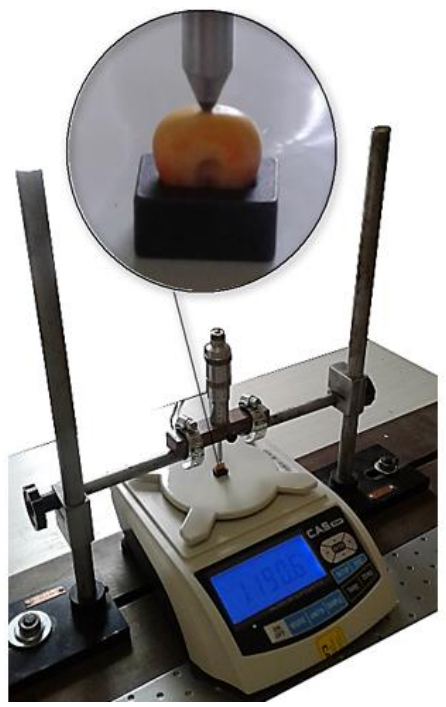

Fig. 1. Equipment for the experimental study of Young's modulus of corn grain shell:

a - schematic image; $b$ - photo; 1 - base plate; 2 - rack; 3 - support; 4 - fixing tape;

5 - micrometric depth meter; 6 - rod; 7 - grain; 8 - analytical weighing equipment with stationary platform; 9 - cylindrical indenter with working part diameter $1.13 \mathrm{~mm}$ and working length $3 \mathrm{~mm}$

\section{Materials and methods}

Young's modulus of four subspecies of corn cultivated in Russia on an industrial scale was experimentally studied: dent corn - variety Kadr 443 SV, flint corn - variety Kremen 200 MV, sugar corn - variety Kuban sugar and popcorn - variety Vulcan.

For this purpose, the method of compressing the local section of the protective fruit shell of corn grain within the limits of its elastic deformation was used. At the same time, the area of location of the deformable local area of the protective fruit shell was located in the upper part of the grain as shown in Fig. 1.

Analysis of existing works on this topic was carried out [2-8], and the basic methodology involving the use of the cylindrical indenter was chosen, as well as the reference calculation expression of the form (1) $[2 ; 3 ; 8]$.

$$
E=\frac{0.886 \cdot P \cdot \psi \cdot\left(1-\mu^{2}\right)}{D^{\frac{3}{2}} \cdot d^{\frac{1}{2}}},
$$

where $E$-Young's modulus, MPa;

$P$-resistance to displacement of the cylindrical indenter in the protective fruit shell of corn grain, $\mathrm{N}$;

$\psi$ - elasticity constant;

$\mu$ - Poisson's ratio for the protective fruit shell of grain corn; 
$d$ - cylindrical indenter diameter, $\mathrm{mm}$;

$D$ - displacement of the cylindrical indenter, $\mathrm{mm}$.

The technique used involves establishing an experimental relationship between resistance to displacement of the cylindrical indenter in the protective fruit shell of corn grain $P$ and displacement of the cylindrical indenter within the limits of elastic deformation of the shell $D$, and also requires substantiation and selection of the constant of elasticity $\psi$ and Poisson ratio $\mu$.

To establish the desired experimental relationship, a one-factor experiment was implemented with subsequent statistical processing of the results.

Resistance to displacement of the cylindrical indenter in the protective fruit shell of corn grain was measured by analytical weighing equipment of II-high accuracy class, displacement of the cylindrical indenter - by a micrometric depth meter of the first accuracy class. The humidity of the test grain samples was $12.8 \ldots 13.4 \%$ and was monitored by a well-known laboratory procedure by dewatering the ground grain samples in a drying cabinet, followed by calculating their weight change by weighing before and after drying.

According to the conventional procedure, a group of grains with the same thickness and width of the upper part was selected for each of the four studied corn subspecies. In the protective fruit shell of the selected grains a cylindrical indenter was alternately penetrated to a depth of $1600 \mu \mathrm{m}$. The resistance to penetration was recorded discretely with a stepwise change in the position of the cylindrical indenter with a pitch of $100 \mu \mathrm{m}$. At each position of the cylindrical indenter, the experiment was repeated until a statistically reliable result appeared. The obtained data were recorded in an observational journal and statistically processed, thus illustrating the results of the studies graphically.

The measurement equipment used, and the repetition rate of the experiments made it possible to obtain the results of experiments, the confidence probability of which exceeds $p=0.95$.

Based on the analysis of sources [3; 5-8], it is assumed that the Poisson ratio value for the protective fruit shell of corn grain is 0.35 .

Corn grains can be considered an asymmetric anisotropic body, consisting of various materials, which include fruit and seed shells, as well as endosperm of various chemical composition. In addition, corn grain is a living organism that develops according to the laws of biology and biosymmetry. Proceeding from it, on the basis of techniques of the theory of similarity it is offered to accept a constant of elasticity comparable to the size of the threefold relation of the linear sizes for corn grain $\psi=1.29$ [9].

\section{Results and discussion}

Observations during the experiment showed that the process of penetration of the cylindrical indenter into the body of the protective fruit shell of corn grain consists of the following steps:

- contact of the protective fruit shell with the supporting surface of the cylindrical indenter without deformation of the shell;

- primary installation of the cylindrical indenter in the extremely small local area of the curvilinear surface of the protective fruit shell;

- transition from the primary installation to the beginning of deformation of the shell;

- formation of compressed compacted section of tissues under supporting surface of the cylindrical indenter;

- transition from the formation of a compressed compacted section to the process of stretching the cladding tissues located in the annular area of the peripheral supporting surface of the cylindrical indenter;

- elastic stretching of tissues of this annular area;

- achieving elasticity limit;

- fluidity of cladding tissues;

- reaching the limit value of deformation during tissue fluidity;

- process of rupturing bonds between cells of deformable sheath tissues;

- achieving complete rupture of all tissues of the protective fruit shell of corn grain;

- endosperm deformation. 
All stages are characterized by a change in the resistance to displacement of the cylindrical indenter in the corn grain shell and endosperm. This change is graphically expressed as bends on experimental dependencies represented in Fig. 2.
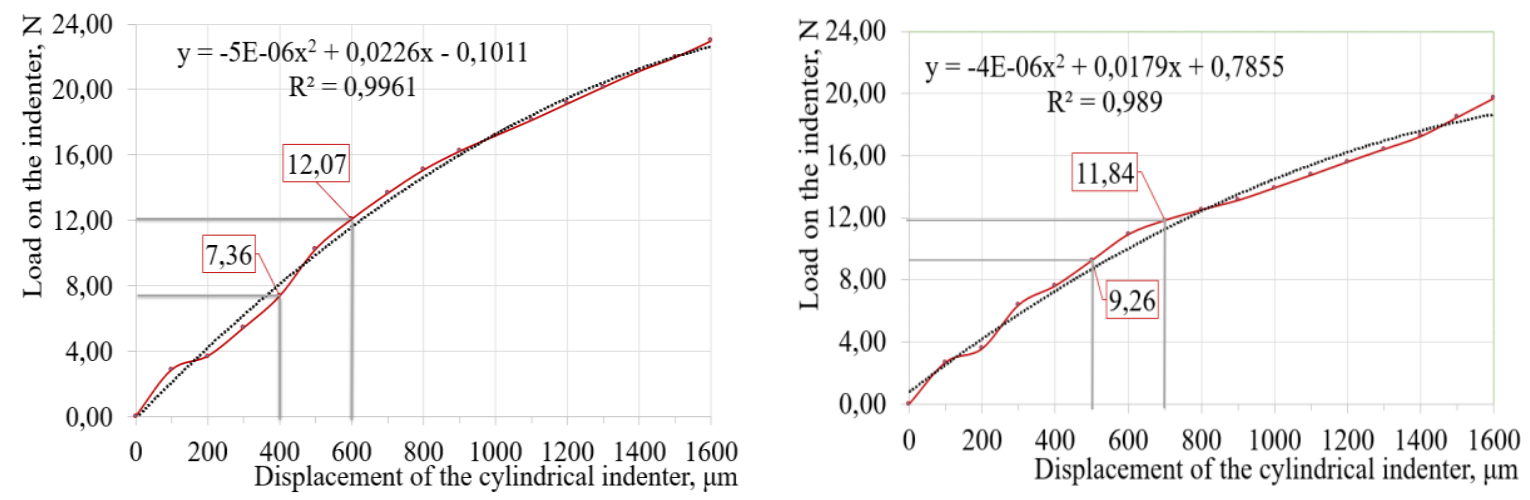

a)

b)
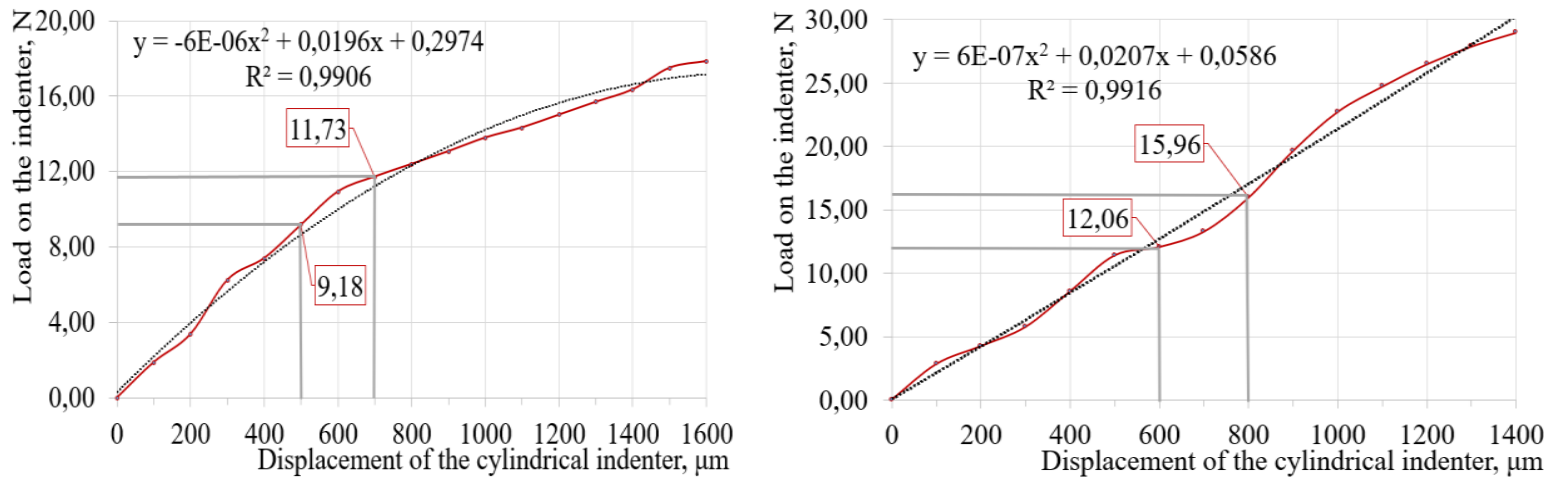

c)

d)

Fig. 2. Results of experimental studies of resistance to displacement of the cylindrical indenter in the protective fruit shell of corn grain: $\mathrm{a}$ - dent corn; $\mathrm{b}$ - flint corn; $\mathrm{c}$ - sugar corn; $\mathrm{d}$ - pop corn

After complete rupture of all tissues of the shell, endosperm deformation begins, which is characterized by resistance stability and graphically expressed by a section of a smooth curve. To determine the Young's modulus, the most scientific interest is the last bend of the curve before the beginning of endosperm deformation, since here the limit of elasticity of the material of the protective fruit shell of the grain is reached. Numerical values of resistance in this area are useful for the Young's modulus calculation by expression (1). The results of the Young's modulus calculation are presented in the form of four intervals of the numerical scale in Fig. 3.

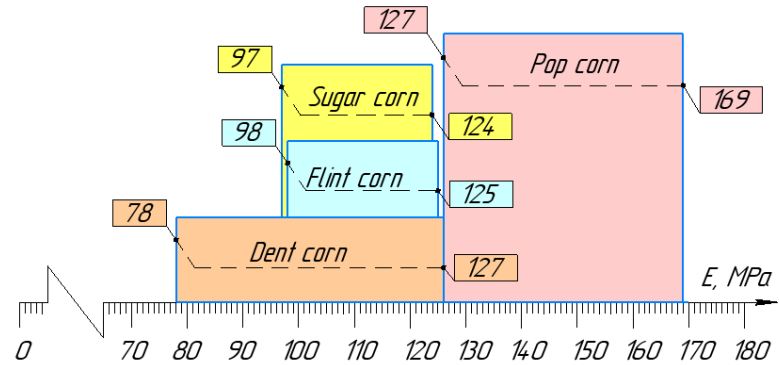

Fig. 3. Results of Young's modulus calculation for protective fruit shell of grains of various corn subspecies

The validity of the results obtained by Young's modulus for dent corn is confirmed by the results of the studies presented in the source [3]. Data analysis in Fig. 3 shows that within a fixed humidity of $12.8 \ldots 13.4 \%$ the protective fruit shell of flint corn and sugar corn grains is characterized by equal values of the Young's modulus. The range of the Young's modulus values of the dent corn grain shell is wider, 
due to the need to protect against mechanical damage, fungal infections and drying, vitreous and floury endosperm at the same time. The maximum value of the Young's modulus for dent corn coincides with the maximum value for flint corn and sugar corn, which is explained by the similarity of the cellular structures of the protective fruit shell of grain of these subspecies of corn.

Young's modulus for popcorn is characterized by values significantly exceeding the values for dent corn, flint corn and sugar corn. This is due to a denser cell structure with an increased ability to resist the penetration of the external environment to the internal tissues of the grain. The protective fruit shell of popcorn is stronger and obviously has rheological properties that differ from other subspecies. This phenomenon requires further in-depth scientific research. At this stage, it is hypothesized that the protective fruit shell of corn grain can be represented as a multi-layered elastic-viscous Maxwell body, each layer of which is characterized by the properties of elastic $G$ and viscous $\eta$ elements, Fig. 4.

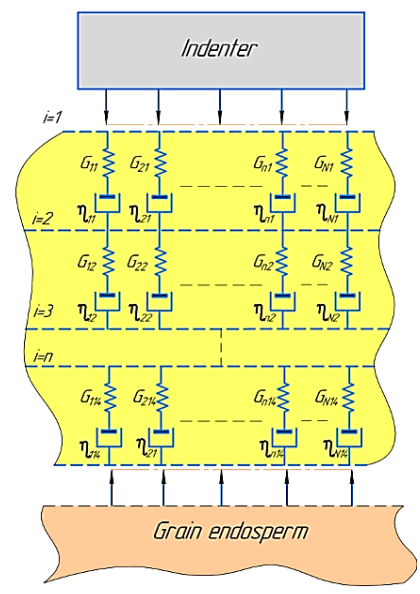

Fig. 4. Rheological model of elastic-viscous protective fruit shell of corn grain

The feasibility of this assumption is confirmed by the results of the studies described in the source [10]. Therefore, the protective fruit shell of corn grains is a structured multilayer system, each layer of cells of which is capable of performing protective functions. Deformation of these layers is carried out sequentially and this determines the limit of elastic properties of the shell. The phenomena occurring in the deformable shell are subject to alternating time-prolonged patterns.

Upon reaching the limit of elasticity of the corn grain shell, the damping effect of the viscous elements $\eta$ ceases and the elastic elements $G$ begin alternately, layer by layer to rupture, so the process of rupturing the bonds between cells is also prolonged over time. This is expressed in Fig. 2 as the last bend before the smooth curve of the graph. It is on the strength characteristics of the elastic elements in this system that the difference in the values of the Young's modulus in different subspecies of corn depends. For popcorn, the elastic characteristics of $G$ are higher than those of the other subspecies studied, its protective shell of grain is denser. This is due to the developed ability to prevent water vapor from leaving the endosperm to the external environment effectively.

Research in this direction will significantly expand the database for scientists, researchers and design engineers working in the field of creating effective working organs for threshing, separating, transporting and other systems for processing corn, operating in stationary conditions of specialized plants. The study of microstructures of shells and internal organs of grain crops and the determination of their mechanical and technological properties is a promising direction of scientific research, requiring versatile scientific research and deep understanding. At this stage in the development of the proposed topic a number of conclusions are drawn as set out below.

\section{Conclusions}

1. The development of highly efficient equipment for processing dent corn, flint corn, sugar corn and pop corn cobs in stationary conditions requires refinement of data on Young's modulus of the protective fruit shell of grain, which is carried out experimentally by the compression method within the limits of elastic deformation of the shell by means of penetration of the cylindrical indenter. 
2. The process of penetration of the cylindrical indenter into the body of the protective fruit shell of corn grain consists of various stages, of which the stage of reaching the limit of elasticity is of greatest scientific interest.

3. The experimental values of resistance to displacement of the cylindrical indenter in the protective fruit shell of grain of corn in the region of reaching its limit of elasticity show the following Young's modulus intervals:

- for dent corn from 78 to $127 \mathrm{MPa}$;

- for flint corn from 98 to $125 \mathrm{MPa}$;

- for sugar corn from 97 to $124 \mathrm{MPa}$;

- for popcorn from 127 to $169 \mathrm{MPa}$.

4. The difference in the values of Young's modulus is explained through the theory of rheology, which allows us to represent the protective fruit shell of the grain as Maxwell's elastic-viscous body. In this case, it can be seen that the reason for the difference in the values of the Young's modulus of the corn shells of the studied subspecies is hidden in the difference in the elastic properties of cells connected in a multilayer structured system.

5. Studying the microstructures of materials from which dent corn, flint corn, sugar corn and popcorn grain organs consist and determining their mechanical and technological properties allows us to form a fundamental scientific basis for designing high-efficiency equipment for the production of seed material with a high yield potential.

\section{References}

[1] Bakharev D., Pastukhov A., Volvak S., Sharaya O. The substantiation of deck parameters of the rotary threshing device. Proceedings of International Conference "Engineering for Rural Development 2019" May 22-24, 2019, Jelgava. Latvia, pp. 481-486.

[2] Shelef L, Mohsenin N.N. Evaluation of the modulus of elasticity of wheat grain. Cereal Chemistry, Vol 44(4), July 1967, pp. 392-402.

[3] Рожковський М.Ф. До визначення механізму деформації і руйнування зернових матеріалів. Вісник аграрної науки, Вип. 7, 2000, с. 50-53. (Rozhkovsky M.F. To determine the mechanism of deformation and destruction of grain materials. Bulletin of agricultural science, Vol. 7, 2000, pp. 50-53). (In Ukrainian).

[4] Калашникова Н.В. Модуль упругости семян зерновых и зернобобовых культур. Механизация и электрификация сельского хозяйства, Вып. 12, 1975, с. 51-52. (Kalashnikova N.V. Modulus of elasticity of seeds of grain and leguminous crops. Mechanization and electrification of agriculture, Vol 12, 1975, pp. 51-52). (In Russian).

[5] Fei D., Wu Y.Z., Han Z.S., Zhang F.W. Experiment on Poisson's ratio determination about corn kernel. Proceedings of "3rd International Conference on Chemical Engineering and Advanced". Vol. 781-784. Trans Tech Publications, 2013, Switzerland, pp. 799-802.

[6] Neto J.P.L., do Nascimento J.W.B., Marques J.I., da Costa C.A. Mechanical properties of grain in silos for simulation designs. Engenharia Agrícola, Vol 36(4), Jaboticabal, July/Aug. 2016, pp. 573580 .

[7] Mohamed A.F. Mechanical properties of corn kernels. Misr Journal of Agricultural Engineering, Vol 26(4), October 2009, pp 1901-1922.

[8] Bo W., Jun W. Mechanical properties of maize kernel horny endosperm, floury endosperm and germ. International journal of food properties, Vol 22(1), 2019, pp. 863-877.

[9] Бахарев Д.Н., Вольвак С.Ф., Пастухов А.Г. Бионические основы конструирования молотильно-сепарирующих систем для початков кукурузы: монография. Издательство ФГБОУ ВО Белгородский ГАУ, п. Майский, 2018. 168 с. (Bakharev D., Volvak S., Pastukhov A. Bionic principles of designing threshing and separating systems for corn cobs: monograph. Publishing House of FSBEI HE Belgorod SAU, Maysky village, 2018, 168 p.). (In Russian).

[10] Anazodo U.G.N. Experimental viscoelastic characterization of corn cob composites under radial compression. Nigerian Journal of Technology, Vol. 6(1), September 1982, pp. 75-85. 